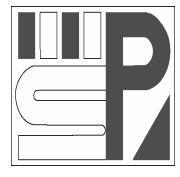

Science Press
Journal of Arid Land

2011, 3(4): 292-299

doi: 10.3724/SP.J.1227.2011.00292

jal.xjegi.com; www.chinasciencejournal.com

\title{
Melting and shrinkage of cryosphere in Tibet and its impact on the ecological environment
}

\author{
JianGuo ZHANG ${ }^{*}$, YingLi WANG, YunSong JI, DeZhi YAN \\ School of Geography, Nantong University, Nantong 226007, China
}

\begin{abstract}
Global warming is having a profound impact on global ecological systems, and has inevitably induced changes in the cryosphere, one of the five layers of the earth. Major changes include the shrinking and reduction in the area and volume of both the mountain glaciers and the ice caps covering the North and South poles, and the melting of permafrost and thickening of the active frost layer. Swift changes in the cryosphere have inevitably induced ecological and environmental changes in its zone. While some of these changes are beneficial to mankind, such as an increase in water circulation, short term increases in water volumes and the enlargement of the cultivatable area, others are extremely hazardous, like the flooding of lowlands caused by an increased sea level elevation, debris flow caused by glaciers, glacier lake bursts, undermined building safety caused by permafrost melting, the deterioration of alpine cold meadows, and the surface aridization and desertification of land. Tibet, having a major part of the cryosphere in China, is home to the most widely spread glaciers and permafrost, which play a vital role in regulating water resources, climate, environment and the ecological safety in China and Asia. However, due to global warming, the glaciers and permafrost in Tibet have recently changed dramatically, exhibiting shrinkage and melting, which threatens long-term water resources, and the ecological and environmental safety of China. Based on existing research, this paper discusses the relationship between global warming and the melting and shrinkage of the cryosphere. The results show that the cryosphere's melting and shrinkage in Tibet are the direct result of global warming. The melting of glaciers has led to a series of disasters, such as changes in river runoff, the heightened frequency of debris flows induced by glaciers and the outbursts of glacier lakes. The melting of the permafrost also resulted in a series of ecological and environmental problems in Tibet, such as the degradation and population succession of the alpine grassland and meadows, the aridization of the land surface, and the occurrence of freeze-thaw erosion.
\end{abstract}

Keywords: Tibet; cryosphere; global warming; ecological environment

The term "Cryosphere" refers to the water on the surface of the earth, which exists in solid form, including ice, snow and permafrost, among which glaciers and permafrost are the two main components (Shi, 2000). As one of five layers of the earth, the cryosphere is heavily influenced by climatic changes. Due to its influences on global and regional climatic changes, its sensitivity to global warming has profound affects, especially in China. As the country with the third largest cryosphere in the world, China is rich in the middle and low latitudes. The area of the cryosphere is about $215 \times 10^{4} \mathrm{~km}^{2}$, accounting for $22.4 \%$ of its terrestrial area, among which, the glacier area reaches
$59,425 \mathrm{~km}^{2}$, accounting for more than $50 \%$ of the glacier area in the middle and low latitudes; the area of permafrost is about $220 \times 10^{4} \mathrm{~km}^{2}$. The area of stable snow (snow days exceed $60 \mathrm{~d}$ ) is about $420 \times 10^{4} \mathrm{~km}^{2}$ (Qin et al., 2006).

The Qinghai-Tibet Plateau, in western China, is the region where the cryosphere is widely spread. The area of the cryosphere reaches more than $150 \times 10^{4} \mathrm{~km}^{2}$, accounting for more than $70 \%$ of the total of Chinese cryosphere (Qiu et al., 2000; Zhong et al.,

Received 2011-06-29; accepted 2011-07-12

*Corresponding author: JianGuo ZHANG (E-mail: sezjg@yahoo.com.cn) 
2006). Tibet, as the main body of Qinghai-Tibet Plateau, the area of the cryosphere accounts for $50 \%$ of that in Qinghai-Tibet Plateau and 33\% of the rest of the country. The development and evolution of the cryosphere in Tibet have great influences on the Tibet Plateau and the ecological environment surrounding the basin of rivers and lakes in China, and even Asia. The melting and shrinkage of the cryosphere may cause a series of ecological environmental disasters, like glacier lake bursts, debris flow caused by glaciers, the deterioration of alpine cold meadow, an increase of freeze-thaw erosion, land aridization and desertification. This paper emphasizes the current condition of melting and shrinkage of the cryosphere and its probable ecological disasters.

\section{Study area}

\subsection{Glaciers in Tibet}

The Tibet Plateau has the most glaciers in China and is an area where mountain glaciers are the most developed in the world. Large numbers of middle-latitude and low-latitude mountain glaciers are distributed among the gigantic transmeridional mountains and the Hengduan Mountain Ranges with a south-north trend in the east. The number of glaciers in the Tibetan autonomous region is 22,468 , accounting for $48.53 \%$ of the total glaciers in China (Table 1). The area of the glaciers reaches $28,645 \mathrm{~km}^{2}$, which occupies $48.22 \%$ of the total glacier area in China. The annual glacial run-off is $349.15 \times 10^{8} \mathrm{~m}^{3}$, accounting for $57.7 \%$ of that in China. The glacial run-off is an important source for the rivers and lakes in Tibet.

The glaciers in Tibet are mainly distributed in mountainous regions like the Himalayan Mountains, the Nyenchen Tonglha Mountains, on the southern slope of the eastern ridge of the Karakoram Range, on the south slope and inner plateau of the Kunlun Mountains, and belonging to the external drainages such as the Ganges River (the Brahmaputra River, etc.), Indus River (Shiquan River and Sutlej River), Lantsang River, Nujiang River and the blind drainages of the ChangTang Plateau. Due to the long span of south-north and west-east, there are great regional differences in developing conditions of water and heat, glacier distributions and types.

\subsection{Permafrost in Tibet}

The Qinghai-Tibet Plateau features a high altitude and cold climate, which determines the existing condition and distribution of the plateau permafrost. The highest and the largest area of permafrost occurs in the Qinghai-Tibet Plateau, which reaches more than $150 \times 10^{4}$ $\mathrm{km}^{2}$ and accounts for $70.6 \%$ of the permafrost area in High Asia. If taking the permafrost area in Hengduan Mountains and Himalaya Mountains are taken into account, the plateau permafrost could occupy $75 \%$ (Qiu, 2000; Wang et al., 2001).

Tibet, the main body of the Qinghai-Tibet plateau, is cold in climate and has the most developed permafrost. In such areas, three kinds of permafrost have been shaped: the permafrost in the north which has existed for many years, the plateau island-shaped permafrost in the center and south, and the seasonally permafrost in the Brahmaputra River valley and other low-altitude areas. According to preliminary estimates, total permafrost area in Tibet is nearly $70 \times 10^{4} \mathrm{~km}^{2}$, which accounts for half of the permafrost area in the Qinghai-Tibet Plateau. And it is a region where the permafrost is most widely distributed in China.

Table 1 The glacier and the glacial runoff of six provinces in Western China

\begin{tabular}{|c|c|c|c|c|c|c|}
\hline Province & $\begin{array}{l}\text { Area of glacier } \\
\quad\left(\mathrm{km}^{2}\right)\end{array}$ & $\begin{array}{c}\text { Percentage of glacier } \\
\text { area in China } \\
(\%) \\
\end{array}$ & $\begin{array}{l}\text { Glacier melting } \\
\text { water runoff } \\
\quad\left(10^{8} \mathrm{~m}^{3}\right) \\
\end{array}$ & $\begin{array}{c}\text { Percentage of the glacier } \\
\text { melting water runoff in } \\
\text { China }(\%)\end{array}$ & $\begin{array}{l}\text { Mountainous } \\
\text { runoff } \\
\left(10^{8} \mathrm{~m}^{3}\right) \\
\end{array}$ & $\begin{array}{l}\text { Proportion of ice and } \\
\text { snow melting water } \\
(\%)\end{array}$ \\
\hline Gansu & 866 & 1.5 & 10.72 & 1.8 & 299 & 3.6 \\
\hline Qinghai & 3,675 & 6.2 & 23.76 & 3.9 & 622 & 3.8 \\
\hline Xinjiang & 25,342 & 42.7 & 201.50 & 33.3 & 793 & 25.4 \\
\hline Tibet & 28,645 & 48.2 & 349.15 & 57.7 & 4,064 & 8.6 \\
\hline Yunnan and Sichuan & 878 & 1.5 & 19.52 & 3.2 & & \\
\hline Total & 59,406 & 100.0 & 604.65 & 100.0 & & \\
\hline
\end{tabular}

Note: Data are from Yang (1991) and Shi (2000). 


\section{Cryospheric response to global war- ming}

\subsection{Evidence of recent climate warming in the Ti- bet Plateau}

From the late $19^{\text {th }}$ century to the 1980 s, the average global temperature has increased about $0.6^{\circ} \mathrm{C}$ (Wang, 1994). Temperature changes in Tibet over the past century were consistent with the changes in average global temperature, but had distinct regional characteristics.

Based on the data analyses of the meteorological stations in Tibet, the mean monthly temperatures in 36 stations from 1961 to 2000 , the monthly maximum and minimum temperatures, the daily range of temperatures in 16 stations from 1961 to 2000 , and the annual average temperatures showed a warmer increase in most parts of Tibet from 1961 to 2000. The areas of significant temperature increases are distributed in the east along the river, the center and western part of Nakchu and Agari prefecture. The warming rates in autumn and winter in most parts are beyond $0.10^{\circ} \mathrm{C} / 10 \mathrm{a}$ with an asymmetrical increase. In most parts, the highest and lowest temperature increased significantly, but the rise in maximum temperature was less than the rise in minimum temperature. The average temperature increased in high altitude areas more than in low altitude areas. And altitudes above 4,000 $\mathrm{m}$ the increase were the strongest. The summer warming was weaker than other seasons; and the autumn warming. From 1961 to 2000 , and the average annual temperatures in Tibet increased at the rate of $0.26^{\circ} \mathrm{C} / 10 \mathrm{a}$. Such an increasing rate is significantly higher than that in China and in the world (Du, 2001). Xu et al. (2006) also testified that the average monthly temperatures of the whole year in Tibet showed a warming trend from 1961 to 2001, and that the percentage increase was more than $80 \%$ in most months, with the greatest increases exceeded $90 \%$ in November, December, January and March. According to the statistics from the stations, the average annual temperatures increased by 96.3\% (Xu et al., 2006). The Meteorological Bureau in Tibet autonomous region also indicated that due to the impact of global warming, mean annual temperatures in Tibet have been rising at the rate of about $0.3^{\circ} \mathrm{C} / 10 \mathrm{a}$, significantly higher than China's entire country rate of $0.4^{\circ} \mathrm{C} / 100 \mathrm{a}$. Tibet's increasing rate is 7.5 times as large as that of China (Deji, 2007).

\subsection{The environmental responses of cryosphere to modern climate changes: melting and shrink- age of cryosphere}

The Cryosphere is not only an important factor of the formation of the Tibetan Plateau climate, but it is also the most sensitive indicator of global changes. The response of the cryosphere in Tibet to climate change is obvious, and is significantly different between regions.

2.2.1 The response of glaciers in Tibet to climate changes

In recent years, a significant number of research has indicated that global warming is threatening Tibetan glaciers represented by the Nebuchadnezzar glacier. There are the signs of glaciers obvious thinning, and the speed of glacier shrinkage is fast (Ren et al., 1991; Wang et al., 2004). In 2005 the Everest expedition team, while inspecting the Rongbuk Glacier on the northern slope of Mt. Everest, found that the glaciers on the northern slope shrank incredibly, compared to 2002. The East Rongbuk Glacier in the upper ablation zone raised $50 \mathrm{~m}$ in 3 years, from $6,350 \mathrm{~m}$ to $6,400 \mathrm{~m}$ (Zhao, 2005). In the next 50 years, it is predicted that the glacier areas in China will decrease $27.2 \%$ and the altitudes of three main types of glacier balanced lines will raise $23 \mathrm{~m}, 168 \mathrm{~m}$ and $138 \mathrm{~m}$ (Qiu et al., 2006). In the $21^{\text {st }}$ century, the decrease proportion of glaciers in China may decrease between $30 \%$ and $67 \%$, which means the glacier area will decrease $1.8 \times 10^{4}-$ $4.0 \times 10^{4} \mathrm{~km}^{2}$, and the volume reduction will be 1,690 $3,760 \mathrm{~km}^{3}$ (Shi, 2000).

\subsubsection{Response of many-year permafrost in Tibet to climate changes}

In the last 30 years, various types of permafrost in Tibet have shown different degrees of degradation, which is manifested by the increase in ground temperature, narrowing of the permafrost area, thinning of the permafrost thickness and even disappearance. Degradation of many-year permafrost first occurred in island-shaped permafrost zone, which is characterized by seasonal freezing depth decreases, and melting depth increases (Wang, 1993; Wang, 1997). The soil temperatures in the inner areas of many-year perma- 
frost with a large area increased. Since the 1970s, the mean annual ground temperatures of the permafrost in the Qinghai-Tibet Plateau have increased by $0.1-0.5^{\circ} \mathrm{C}$. Diverged permafrost and sandwich melting were formed on the edge in an upward vertical direction. The lower boundary of permafrost distribution increased $40-80 \mathrm{~m}$, and the total area of permafrost in the plateau decreased $10 \times 10^{4} \mathrm{~km}^{2}$. The observation on the southern slope of the Tanggula Mountain indicated that the ground temperatures in $15 \mathrm{~m}$ and $20 \mathrm{~m}$ layers increased $0.6-0.8^{\circ} \mathrm{C}$ and $0.3-0.5^{\circ} \mathrm{C}$, respectively, from 1975 to 1994 essentially melting part of the permafrost. In the next 50 years, $80 \%$ to $90 \%$ of the island-shaped permafrost will have degraded in Qinghai-Tibet Plateau. Seasonal melting depth will increase. The lower boundary of permafrost will lift 150-250 m. The meta-stable and stable permafrost temperature will increase $0.5-0.7^{\circ} \mathrm{C}$ (Qiu et al., 2006).

\section{The impact of a melting and shrink- ing cryosphere age on the ecologi- cal environment in Tibet}

\subsection{The impact of melting glacier on ecological environment in Tibet}

\subsubsection{Glacier melting and river runoff in Tibet}

Glaciers are an important solid water resource of China. The volume of ice reserve is about $5,600 \mathrm{~km}^{3}$ and the volume of the melting water is $5.0 \times 10^{12}$ $\mathrm{m}^{3}$, equivalent to the annual run-off of five Yangtze Rivers which is stored in solid form in the western mountains. The melting water from glaciers provides a continuous supply, regulating the run-off of western rivers. The volume of average glacier melting water every year is about $6.0 \times 10^{10} \mathrm{~m}^{3}$ (Qiu et al., 2006).

Melting water from glaciers is an important source for the Tibetan rivers. The region's glacial runoff is $3.4915 \times 10^{10} \mathrm{~m}^{3}$, accounting for $57.7 \%$ of glacial runoff in China, up to $8.6 \%$ of the proportion is supplied by glacier melting. The proportion of melting water from the Indian River system, Ganges River, and Nujiang River in Tibet reaches up to $44.8 \%, 9.1 \%$ and $8.8 \%$, respectively (Table 2 ).

Glacier plays a role of regulating river run-off within a year. Due to lack of heat with the years of low temperature and wetness, there is a weak melting of glaciers, which leads to ice accumulation. Because of an increase in sunny weather and drought, the glacier intensifies releasing large amounts of melting water, and compensating for reduced rainfall, causing a river water shortage. According to Yang (1991), the rivers of snow-ice melting and rainwater-ice melting have a larger proportion of supply water from glacial melting which can adjust to river run-off reducing the variable rate of annual run-off and keeps a more stable runoff. Generally, the value of annual variation coefficient of these rivers is 0.10 to 0.20 (Wang et al., 2001). Therefore, if glacier lake outburst doesn't happen in the rivers with a large supply of the amount of glacial melting water, the risk of droughts and floods in these areas is relatively small.

Glacial shrinkage in Tibet, caused by global warming, would lead to an overdraft of the glacier reserve. In the short term, the river supply will improve and the river water in Tibet will increase significantly. But in the long term, the glacier will gradually wither away, and the supply of water from glacier melting to the river will gradually reduce. The chances for these rivers to dry up or be threatened by droughts and floods will increase (Shi, 2001). Studies show that breaking the balance of glaciers will bring about unpredictable ecological problems. Since the 1990s, in the Northwest China, glacial run-off increased more than $5.5 \%$ due to reduced glacial reserves. If global warming continues at the current rate, most of the glaciers in China will wither away by 2100 , and some rivers in the downstream of glaciers will dry up (Yao, 2004).

Table 2 The glacial runoff of main exterior drainages in Tibet

\begin{tabular}{lcccccc}
\hline Drainage basin & $\begin{array}{c}\text { Area of glacier } \\
\left(\mathrm{km}^{2}\right)\end{array}$ & $\begin{array}{c}\text { Percentage } \\
(\%)\end{array}$ & $\begin{array}{c}\text { River } \\
\text { section }\end{array}$ & $\begin{array}{c}\text { Amount of river runoff } \\
\left(10^{8} \mathrm{~m}^{3}\right)\end{array}$ & \multicolumn{2}{c}{$\begin{array}{c}\text { Glacier melting water } \\
\text { runoff }\left(10^{8} \mathrm{~m}^{3}\right)\end{array}$} \\
\hline Nujiang River & $1,730.20$ & 7.21 & In Tibet & 409.0 & 35.98 & 8.8 \\
Ganges River & $18,161.96$ & 75.62 & In Tibet & $3,101.1$ & 280.48 & 9.1 \\
Indus River & $1,451.26$ & 6.04 & In Tibet & 17.2 & 7.70 \\
\hline
\end{tabular}

Note: The data is from Shi (2000). 
3.1.2 Glacier melting and glacial lake flood outburst Immediate floods caused by glacier lake bursts are a common flood hazard in the mountains in Tibet. Floods caused by heavy rain or snow melting are different from this sudden flood, in which flood peak is high, flood volume is small, flood is rapid, and the hydrograph is pointed in thin, single-peak type, which is difficult to prevent. Global warming is an important reason for glacial lake outburst flood (GLOF). First, large amount of water from melting glaciers will make the water level rise, resulting in the overflow by filled glacial lakes or the final collapse of piping dams and the formation of GLOF. Second, when the glacier tongue approaches the lake or sticks in the lake to form steep high tongue, the end of the tongue will collapse in the strong ablation. A lot of ice falls into the lake, triggering huge waves and directly lashing glacial lake dams. At the same time, instable glacial till or slope wash around the lake are also induced to collapse or slide into the lake. Together, with a large amount of collapsing ice, the water level suddenly surges, causing the overflow of lakes or increased hydrostatic pressure due to the higher water level. The rapid expansion of the piping leads to the collapse of lake dams. For example, the glacial till lake located in Poge, a snow mountain of Pijia, collapsed on 23 July, 1972. According to the data analysis in the Dêngqên county weather station in Tibet, July of 1997 was the hottest month since meteorological records existed in the 1950s, and the monthly mean temperature was $2.2^{\circ} \mathrm{C}$ higher than the previous period averages. The glacier melting water increased, the ice collapsed and fell into the lake, causing a GLOF (Xu, 1989).

The central Himalayas is one of these areas where sudden floods of glacial lake happen frequently. Here, the glacial lakes are mainly glacier end moraine lakes, with about $1 / 2$ of the total number of various types of high mountain lakes and $2 / 3$ of the total storage capacity. Thirty four glacier end moraine lakes are identified to be dangerous, with average depth of $31 \mathrm{~m}$ and the total water storage capacity between $1.0 \times 10^{7} \mathrm{~m}^{3}$ and $3.0 \times 10^{7} \mathrm{~m}^{3}$. Most of these dangerous end moraine lakes formed in the last ice retreat of the Little Ice Age. In the last 50 years, large outburst events occurred at least 20 times in the moraine lakes on the northern and southern slopes of the
Himalayas, of which 3/4 occurred in Tibet, China. The outburst happening in Tseringmacuo (an end moraine of glacier lake), the source of Zhangzangbu gully of the Boqu River in Nyalam county in the summer of 1981, destroyed the China-Nepal roads over nearly 50 $\mathrm{km}$ and almost all the bridges and culverts including the Friendship Bridge and Puerping Bridge. Sun Kosi hydropower in Nepal was also partly destroyed. The loss caused by the flood was estimated at nearly 3 million US dollars (Shi, 2000). In the summer of 1982, the outburst in Jincuo (glacial end moraine lake) in Dinggyê county resulted in the flooding of eight villages and large tracts of farmland, washing away 1,600 livestock. The Nianchu River, a branch of Brahmaputra River, derives from the northern slope of Himalayas Mountains. Using aerial photographs and Landsat image statistics, 49 glacial lakes were indentified, and including the Sanwong Lake (also named Shiecuo, a moraine lake) with maximum area of 5.4 $\mathrm{km}^{2}$. On July 16, 1954, the end of a glacier collapsed for the second time. Huge chunks of ice slid into the lake, resulting in a sudden rise in the water level and an overflow of the lake. The lake outburst happened at $7 \mathrm{pm}$ of the evening and about $2.5 \times 10^{8} \mathrm{~m}^{3}$ water surged downstream, causing flooding rarely seen in history. According to the investigations in Delhi township (about $10 \mathrm{~km}$ from the lake), the maximum peak flow reached $1.0 \times 10^{4} \mathrm{~m}^{3} / \mathrm{s}$, causing heavy losses downstream (Chen et al., 1996; Vuichard et al., 2000). In 2000, the glacial lake outburst that occurred in Chongbayongcuo, the source of Nieruzangbu in Kangma county, resulted in flooding across the Nianchu Lake with heavy losses in Kangma, Gyantse and Bailang counties.

\subsubsection{Glacier melting and glacial mud-rock flow}

Glacial mud-rock flow is a special flood which contains large amount of loose solid materials, such as silt, sand, and gravel in the modern glacier and snow accumulation region. The solids in the fluid are mainly formed by the old and new tills, resulting from the modern and ancient glaciers. The water is mainly supplied by intense melting of glaciers and snow, outburst glacial lake, and the strong water currents generated by the rapid melting of snow and ice. The distribution of debris glaciers in Tibet can be divided into three areas, the oceanic glacier area, the continental glacier area and the transitional glacier area. 
Mud-rock flow in the oceanic glacier area is mainly distributed in southeast Tibet and the Hengduan Mountains. Particularly, the flow is densely distributed among several major tributaries in the lower reaches of the Brahmaputra Rives-Yigongzangbu, Parlung Zangbo, Dongjiu, Nyang, Jingzhu, Dibang and Zayüqu rivers, which flows directly out of the borders. The total number of mud-rock flows is estimated to being more than a hundred. Among them, the outbreak of glacial mud- rock flows in near 40 gullies and valleys like the famous Guxiang gully, Pailong gully, Dongrunongba, are large, with high frequency and heavy damage. In $1953,1.0 \times 10^{7} \mathrm{~m}^{3}$ of sediment moved out of the mountains, caused by the great glacial mud-rock flow in the Guxian gully, instantly forming a huge, alluvial fan of glacial mud-rock flow spreading $3 \mathrm{~km}^{2}$, blocking off the Palongzangbu River, flooding a large area of farmland, and forming a $5-\mathrm{km}$ long and 1-km wide lake in the upper streams (Shi, 2000). The glacial mud-rock flow in the continental glacier area has a scattered distribution, and totals less than the oceanic glacier area, with a longer outbreak cycle. It is mainly distributed on the central and northern slope of the western part of the Himalayas, in the eastern part of the Tanggula Mountain and other regions.

The glacial mud-rock flow formed by the moraine glacier lake outburst is developed in the transitional area between the oceanic and continental glacier areas, mainly in the central and western section of the Himalayas. For example, on the afternoon of September 21, 1964, because the outburst of an end moraine lake, caused a large scale glacial mud-rock flow in Jilai Pu gully of Dingjie county, Tibet. The flow length reached $30 \mathrm{~km}$, and forming a giant deposit ridge (Shi, 2000).

Tibetan glacial debris flow is essentially the product of a serious shrinkage of glaciers in Tibet. Due to glacier retreat, a large number of clastics (mainly inner moraine, end moraine and center moraine) are freed from the ice, providing a source of solid materials for the formation of glacial debris flow. At the same time, also due to glacial retreat, large areas of bedrock are exposed, which provides a broader space for periglacial process, mainly including gelifraction, speeding up the accumulation and removal of the soil, sand and rocks, and increasing the size of of glacier debris flow. As a result of climate warming, the accelerated melting and shrinkage of glaciers in Tibet also provide abundant sources of water for the formation of glacial debris flow, the formation of which was intensified due to multiple factors.

\subsection{Influence of permafrost degradation on ecol- ogy in Tibet}

Permafrost has a significant impact on the hydrology, ecology and climate of cold regions in China. It is estimated that the permafrost in the Qinghai-Tibet plateau discharges water reaching up to $5.0 \times 10^{9}-1.1 \times 10^{10}$ $\mathrm{m}^{3}$ per year in recent decades because of its degradation. In addition to the water joining the hydrologic cycle in the freeze thaw process, the impact on hydrology, ecology and climate is significant. Permafrost and water exchange are the key factors to maintain the stability of an ecosystem in cold regions. In recent decades, the ecosystem degradation in the Yangtze and Yellow river regions, the significant hydrological changes in the regional rivers, lakes, and the swamps and wetlands are closely related to the changes of soil freeze-thaw cycles and permafrost degradation (Qin et al., 2000).

\subsubsection{Permafrost degradation and river runoff}

Tibet is full of permafrost regions with large areas of continuous permafrost, island-shaped permafrost and seasonal permafrost. All of which have a major impact on the formation and regulation of river runoff. On one hand, permafrost melting provides water for run-off. On the other hand, the presence of permafrost can prevent infiltration of precipitation, cutting off the transformation from precipitation to groundwater, so that the runoff process becomes concentrated and lasts for a short time. Large areas of lakes, alpine meadow marshes and river beaches maintain and regulate precipitation run-off, having a significant effect on the stable annual distribution of runoff. Permafrost degradation decreases the saving of water runoff on and in the permafrost layer. Water runoff supply of the permafrost layer reduces the plateau river supplies.

Since the 1990s, the temperatures along Lhasa River increased by $0.54^{\circ} \mathrm{C}$ over 10 years, mainly in autumn and winter. Based on climate data of the last 40 years (1963-2004) and monthly runoff over 28 years (1976 to 2004), Gong (2006) studied the permafrost and hydrologic responses in the Lhasa River with per- 
mafrost in high altitudes. The results showed that run-off in winter made a significant response to the increase of temperatures from November to February. The increase percentage was $16 \%$ between December to February, and $22 \%$ in February. Hydrothermal correlation analysis showed that the surface temperature from October to November increased $0.8-0.9^{\circ} \mathrm{C}$, leading to an increase in winter river water, while the changes in the depth and temperature of seasonal permafrost in the $0.9-1.5 \mathrm{~m}$ depth range caused the fluctuation of runoff. Climate warming in the 1990s made the depth of seasonal permafrost. The hydrological response of the winter run-off in permafrost regions was faster and more significant than the temperature (Gong, 2006).

\subsubsection{Permafrost degradation and vegetation}

The impact of permafrost on vegetation is mainly manifested in two aspects: the permafrost layer can effectively prevent infiltration of surface water and soil moisture, increasing water in the root of plants. On the other hand, the organic matter of lixiviation in the soil concentrates on the permafrost layer, thus increasing the nutrient content in the roots of the plants. Permafrost degradation reduced moisture and nutrients in the roots of plants, and dried up marsh, changing physical and chemical soil properties, resulting in alpine meadow and wetland degradation. Based on the studies of the impacts of permafrost environment elements on the alpine ecosystems in the Qinghai-Tibet plateau in the dual roles of the effect of humans and climate change from the Kunlun Mountains to the Tanggula Mountains, permafrost degradation is the main cause of ecosystem degradation. The unique and fragile alpine ecosystem in permafrost regions of high altitudes has obvious responses to natural and anthropogenic disturbances. In the alpine ecosystems of permafrost distribution areas in the plateau, the alpine meadow and alpine bog meadow ecosystems are most closely related to a permafrost environment. Approaching the upper limit of permafrost depths, the cover and biomass of the alpine meadow and alpine bog meadow significantly decreased, which indicates that the permafrost upper limit depth impacts the alpine meadow cover and biomass. Permafrost degradation will lead directly to the degradation of alpine meadow and alpine bog meadow ecosystems. In the last 15 years, the distribution area of alpine bog meadow in Qinghai-Tibet Plateau decreased 28.11\%, and the distribution area of alpine meadow decreased $7.98 \%$. In addition, as the permafrost upper limit increases, the organic matter in soils of alpine meadow decreased significantly, and the top soil in alpine grassland and meadow became coarse. Maintaining stability in the permafrost environment is of great significance for the stability and the control of desertification for alpine ecosystems.

3.2.3 Permafrost degradation and freeze-thaw erosion

The occurrence and development of freeze-thaw erosion is closely related to permafrost degradation. First of all, permafrost degradation caused by global warming and the effect of humans increase the thickness of the freezing melting layer (active layer), that is, the freeze thaw depth increases, directly strengthening the intensity of freeze thaw erosion; second, in the permafrost zone, the water in the seasonal active layer is blocked by its impermeable lower permafrost layer. Therefore, the water can not only be the main source of water used by vegetation, but also provide the necessary conditions for the development of marsh meadows and wetlands, distributed in sheets and ribbons. With the the permafrost degradation, the active layer (seasonal thawing layer) begins thickening and the water level of regional groundwater and ecological water decreases. The water is no longer up to the top soil, and the soil become dry significantly, decreasing the water which plants can use, resulting in the death of plants with short roots, a loss of biological diversity, and degradation of vegetation. Due to lack of protection from vegetation, the freeze-thaw erosion intensifies. According to our preliminary study, a total area of the freeze-thaw erosion in the Tibet autonomous region reached $664,317.4 \mathrm{~km}^{2}$, accounting for $55.3 \%$ of the land area (Zhang et al., 2006). The worst freeze-thaw erosion areas are distributed in the band edges where permafrost degradation is very serious. Freeze-thaw erosion does great harm to the ecological environment in Tibet, and has a great impact on the sustainable use of grassland resources and the sustainable development in animal husbandry in Tibet. Intense freeze-thaw erosion in Tibet also causes soil degradation and vegetation succession, and speeds up the process of land degradation, such as the formation of bare surface and 
fragmentation. A large area of freeze-thaw desertified land in the plateau has been formed, exerting huge environmental pressures on the ecological security of the palteaus.

\section{Conclusion}

Global warming is generating a profound impact on global ecosystems. Tibet, as a major component of the cryosphere, is also having a corresponding response to global warming. The main manifestation of this response includes: the shrinkage of the glacier area and reduction of glacier volume, and permafrost melting or active layer thickening.

The changes in the Tibet cryosphere cause ecological and environmental changes in these areas. Some

\section{References}

Chen C J, Liu M, Zhang Z. 1996. Outburst conditions of Moraine-Dammed Lakes and their flood estimation in the headwaters of the Nianchu River, Tibet. Journal of Glaciology and Geocryology, 18(4): 347-352.

Cold and Arid Regions Environmental and Engineering Research Institute, Chinese Academy of Sciences. 2005. The degradation of the frozen earth is one of the leading reasons of the Qinghai-Tibet plateau ecological deterioration. [2006-01-16]. http://www.cas.cn/html/ Dir/2005/05/12/8474.htm.

Deji Bianbaciren. 2007. Climate warming speed in Tibet is 7.5 times of the national average. [2008-02-10]. http://www.csonline.com.cn/ news/guonei/200707/t20070723_704120.htm.

Du J. 2001. Change of temperature in Tibetan Plateau from 1961 to 2000. Acta Geographica Sinica, 56(6): 682-690.

Gong T L, Liu C M, Liu J S. 2006. Hydrological response of Lhasa River to climate change and permafrost degradation in Xizang. Acta Geographica Sinica, 61(5): 19-526.

Qin D H, Xiao C D, Ding Y J, et al. 2006. Progress on cryospheric studies by international and Chinese communities and perspectives. Journal of Applied Meteorological Science, 17(6): 649-656.

Qiu G Q, Zhou Y W, Cheng G D, et al. Geocryology in China. Beijing: Science Press, 2000: 43-44.

Ren J Y, Ji Z Y. 1991. Climatic warming for recent 10 years and its effects. Arid land Geography, 14(4): 42-47.

Shi Y F. 2000. Glaciers and Their Environments in China-the Present, Past and Future. Beijing, Science Press, 1-2, 190-197, 234-252.

Shi Y F. 2001. Predictable main change of environment in Qinghai-Tibet Plateau. Journal of Salt Lake Research, 9(1): 2-3.

Vuichard D, Zimmerman M. 1986. The landmoche flash-flood, Khumbuhimal, Nepel: cause and consequences. Mountain Research and Development, 7(2): 91-110.

Wang N L, Yao T D. 2001. Evidences for global warming in the $20^{\text {th }}$ of these changes are beneficial to mankind, such as the acceleration of the global water cycle, increasing the short-term water resources and expanding cultivable area, etc. But other changes bring more harm to mankind, which is manifested as: accelerated glacier melting increasing the frequency of disasters, such as flooding from glacier debris flows and glacial lake outburst flood; the degradation of alpine permafrost caused the degradation of alpine meadows and alpine bog meadows, and the enhancement of freeze-thaw erosion, thus contributing to the surface aridization and desertification.

\section{Acknowledgement}

The study was funded by the National Natural Science Foundation of China (40901140).

century from cryosphere. Advance in Earth Sciences. 16(1): 98-104.

Wang S L. 1993. Evolution of permafrost along the Qinghai-Tibet Road in the past several decades. Arid Land Geography, 16(1): 1-7.

Wang S L. 1997. Study of permafrost degradation in the Qinghai Xizang Plateau. Advance in Earth Sciences, 12(2): 164-167.

Wang S W. Introduction to Climate System. Beijing: Meteorology Press, 1994: 54-59.

Wang Y, Li X, Miao Q L. 2004. Analyses on variety characteristics of temperature in Qinghai-Tibet Plateau in recent 50 years. Arid Land Geography, 27(1): 41-45.

Xu D M, Liu C H, Feng Q H. 1989. Dangerous glacial lake and outburst featuresin Xizang Himalayas. Acta Geographica Sinica, 44(3): 343-352.

Xu Z X, Gong T L, Zhao F F F. 2006. Analysis of climate change in Tibetan Plateau over the past 40 years. Journal of Subtropical Resources and Environment, 1(1): 24-32.

Yang Z N. 1991. The Glacial Water Resource in China. Lanzhou: Gansu Science and Technology Press, 81-150.

Yao T D, Liu S Y, Pu J C, et al. 2004. Glacier retreating in High Asia influence the water resources in the Northwest China. Science in China: Series D, 34(6): 535-543.

Zhang J G, Liu S Z, Yng S Q. 2006. Classification and assessment of freeze-thaw erosion in Tibet. Acta Geographica Sinica, 61(9): 911-918.

Zhao Y H. 2005 China's mount Everest comprehensive expedition found that the glacier shrinked seriously on the north slope of mount Everest. [2006-04-11]. http://news.sina.com.cn/c/2005-05-12/ $09225866037 \mathrm{~s} . \mathrm{shtml}$.

Zhong X H, Liu S Z, Wang X D, et al. 2006. A research on the protection and construction of the state ecological safe shelter zone on the Tibet plateau. Journal of Mountain Science, 24(2): 129-136. 